\title{
Characterization and Conduction Mechanism of Highly Conductive Vanadate Glass
}

\author{
Tetsuaki Nishida, ${ }^{1,}{ }^{*}$ Shiro Kubuki, ${ }^{2}$ Koken Matsuda, ${ }^{2}$ Yuki Otsuka ${ }^{2}$
}

1 Department of Biological and Environmental Chemistry, Faculty of Humanity-Oriented Science and Technology, Kinki University, lizuka, Fukuoka 820-8555, Japan
2 Department of Chemistry, Graduate School of Science and Technology, Tokyo Metropolitan University, Hachi-Oji, Tokyo 192-0397, Japan
${ }^{*}$ Corresponding author's e-mail address: nishida@fuk.kindai.ac.jp

RECEIVED: October 9, 2015 * REVISED: November 26, 2015 * ACCEPTED: November 27, 2015

THIS PAPER IS DEDICATED TO DR. SVETOZAR MUSiĆ ON THE OCCASION OF HIS 70 TH BIRTHDAY

\begin{abstract}
This paper reviews recent studies of highly conductive barium iron vanadate glass with a composition of $20 \mathrm{BaO} \cdot 10 \mathrm{Fe}_{2} \mathrm{O}_{3} \cdot 70 \mathrm{~V}_{2} \mathrm{O}_{5}$ (in $\mathrm{mol} \%$ ). Isothermal annealing of the vanadate glass for several ten minutes at a given temperature, higher than glass transition temperature or crystallization temperature, caused an increase in $\sigma$. Substitution of $\mathrm{Cu}^{\prime}\left(3 d^{10}\right), \mathrm{Zn}^{\prime \prime}\left(3 d^{10}\right)$ and $\mathrm{Cu}^{\prime \prime}\left(3 d^{9}\right)$ for Fe"l' $\left(3 d^{5}\right)$ was investigated to elucidate the effect of electron configuration on the conductivity $(\sigma)$. A marked decrease in the activation energy of conduction $\left(E_{\mathrm{a}}\right)$ was also observed after the annealing. Values of $E_{\mathrm{a}}$ were correlated to the energy gap between the donor level and the conduction band (CB) in the $n$-type semiconductor model. Isothermal annealing of $\mathrm{Zn}$ "-substituted vanadate glass $\left(20 \mathrm{BaO} \cdot 5 \mathrm{ZnO} \cdot 5 \mathrm{Fe}_{2} \mathrm{O}_{3} \cdot 70 \mathrm{~V}_{2} \mathrm{O}_{5}\right)$ at $450{ }^{\circ} \mathrm{C}$ for $30 \mathrm{~min}$ showed an increase in $\sigma$ from $2.5 \times 10^{-6}$ to $2.1 \times 10^{-1} \mathrm{~S} \mathrm{~cm}^{-1}$, which was one order of magnitude larger than that of non-substituted vanadate glass $\left(3.4 \times 10^{-2} \mathrm{~S} \mathrm{~cm}^{-1}\right)$. Under the same annealing condition, $\sigma^{\prime}$ s of $2.0 \times 10^{-1}$ and $3.2 \times 10^{-1} \mathrm{~S} \mathrm{~cm}^{-1}$ were observed for $20 \mathrm{BaO}^{\circ} 5 \mathrm{Cu}_{2} \mathrm{O} \cdot 5 \mathrm{Fe}_{2} \mathrm{O}_{3}$ $.70 \mathrm{~V}_{2} \mathrm{O}_{5}$ and $20 \mathrm{BaO} \cdot 5 \mathrm{CuO} \cdot 5 \mathrm{Fe}_{2} \mathrm{O}_{3} \cdot 70 \mathrm{~V}_{2} \mathrm{O}_{5}$ glasses, respectively. These results demonstrate an increase in the carrier (electron) density in the $\mathrm{CB}$, primarily composed of anti-bonding $4 \mathrm{~s}$-orbitals.
\end{abstract}

Keywords: highly conductive vanadate glass, heat treatment, structural relaxation, small polaron hopping, n-type semiconductor.

\section{INTRODUCTION}

$\mathbf{S}$ ILICATE $\left(\mathrm{SiO}_{2}\right.$-based) glass is generally known as an "insulator" having the resistivity $(\rho)$ of the order of "terra" $\Omega \mathrm{cm}$. However, silicate glass, synthesized by using recycling fly ash (coal ash) containing $\geq 12$ wt $\% \mathrm{Fe}_{2} \mathrm{O}_{3}$ after isothermal annealing at $1100{ }^{\circ} \mathrm{C}$ for $1 \mathrm{~h}$, showed $\rho$ of "mega" $\Omega \mathrm{cm} \cdot{ }^{[1,2]}$ This iron-containing silicate glass had decrease in $\rho$ or increase in conductivity $(\sigma)$. A change in the property of fly-ash recycled glass was ascribed to the precipitation of magnetite $\left(\mathrm{Fe}_{3} \mathrm{O}_{4}\right)$ particles in the matrix. Formation of $\mathrm{Fe}_{3} \mathrm{O}_{4}$ was due to the partial reduction of $\mathrm{Fe}_{2} \mathrm{O}_{3}$ caused by several weight percent of carbon atoms, which were originally presented in the fly ash. ${ }^{[1,2]}$

The presence of $\mathrm{Fe}_{3} \mathrm{O}_{4}$ particles was confirmed from the Mössbauer spectra of fly-ash recycled glass. ${ }^{[1,2]}$ The fraction of magnetite particles increased after a prolonged annealing at $1100{ }^{\circ} \mathrm{C}^{[1,2]} \mathrm{Fe}_{3} \mathrm{O}_{4}$ are generally known as semiconductor and may have created a "pathway" of the electric conduction along the crystalline particles. Möss-

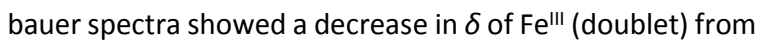
$0.32-0.34 \mathrm{~mm} \mathrm{~s}^{-1}$ to $0.14-0.15 \mathrm{~mm} \mathrm{~s}^{-1}$ after the annealing. This indicates an increased covalency of the distorted $\mathrm{Fe}^{\text {III }} \mathrm{O}_{4}$ tetrahedra occupying the network forming (NWF) sites in the glass matrix. In the as-quenched glass, another doublet of $\mathrm{Fe}^{\| \prime}\left(\delta=1.02-1.09 \mathrm{~mm} \mathrm{~s}^{-1}\right)$ was also observed, which was assigned to octahedral species occupying network modifying (NWM) sites. After the annealing, Fe"l occupied tetrahedral NWF sites, as revealed from the values of $\delta\left(0.81-0.86 \mathrm{~mm} \mathrm{~s}^{-1}\right)$. This suggests distorted $\mathrm{Fe}^{\mathrm{II}} \mathrm{O}_{6}$ octahedra were transformed to distorted $\mathrm{FeO}_{4}$ tetrahedra during the annealing.

In the fly-ash recycled glass, increase in $\sigma$ from the order of $10^{-8} \mathrm{~S} \mathrm{~cm}^{-1}$ to $10^{-6} \mathrm{~S} \mathrm{~cm}^{-1}$ was observed, which was ascribed to the promotion of electron hopping from $\mathrm{Fe}^{\text {ll }}$ to Fe"ll in the glass matrix. In other words, a "pathway" of the electron hopping was created in the glass-ceramics. Although the fly-ash recycled glass or glass-ceramic has 
attracted much interest, it is noted that the value of $\rho$ was at least of the order of "mega" $\Omega \mathrm{cm}$. This indicates limited industrial applications of glass-ceramic having conductivity $(\sigma)$ ranging from "insulator" to "semiconductor". This leads to interest in as-quenched vanadate $\left(\mathrm{V}_{2} \mathrm{O}_{5}\right.$-based) glass that originally has resistivity of "mega" $\Omega \mathrm{cm}$.

Small polaron hopping theory has been usually applied to describe the conduction mechanism of vanadate glass. ${ }^{[3]}$ Isothermal annealing of alkali vanadate glass, 25 $\mathrm{K}_{2} \mathrm{O} \cdot 10 \mathrm{Fe}_{2} \mathrm{O}_{3} \cdot 65 \mathrm{~V}_{2} \mathrm{O}_{5}$ (composition in mol \%), was carried out at $380^{\circ} \mathrm{C}$ for $10 \mathrm{~min}$. This temperature was higher than the glass transition temperature $\left(T_{\mathrm{g}}\right)\left(217^{\circ} \mathrm{C}\right)$ and also than the crystallization temperatures of $284^{\circ} \mathrm{C}\left(T_{\mathrm{c}}(1)\right)$ and $344^{\circ} \mathrm{C}$ $\left(T_{\mathrm{c}}(2)\right)$. Isothermal annealing at $380^{\circ} \mathrm{C}$ caused a substantial decrease in $\rho$ from $1.6 \times 10^{7} \Omega \mathrm{cm}\left(\sigma=6.3 \times 10^{-8} \mathrm{~S} \mathrm{~cm}^{-1}\right)$ to $2.3 \times 10^{3} \Omega \mathrm{cm}\left(\sigma=4.3 \times 10^{-4} \mathrm{~S} \mathrm{~cm}^{-1}\right) .{ }^{[4,5]}$ Nishida et al. suggested that the lowering of $\rho$ by four orders of magnitude was due to an increased probability of the small polaron hopping from $\mathrm{V}^{\mathrm{V} V}$ (or $\mathrm{V}^{\mathrm{III}}$ ) to $\mathrm{V}^{\mathrm{V}}$. The decrease in quadrupole splitting $(\Delta)$ of Mössbauer spectra measured at room temperature $(R T)$ confirmed a decrease in the distortion of pseudo-1D network structure of $25 \mathrm{~K}_{2} \mathrm{O} \cdot 10 \mathrm{Fe}_{2} \mathrm{O}_{3} \cdot 65 \mathrm{~V}_{2} \mathrm{O}_{5}$ glass. ${ }^{[4,5]}$ Decrease of the distortion of network structure or "structural relaxation" became large after the annealing of several ten minutes. Prolonged isothermal annealing of 25 $\mathrm{K}_{2} \mathrm{O} \cdot 10 \mathrm{Fe}_{2} \mathrm{O}_{3} \cdot 65 \mathrm{~V}_{2} \mathrm{O}_{5}$ glass for more than 150 min resulted in a gradual decrease of $\sigma$ in conjunction with the precipitation of "insulating" $\mathrm{KV}_{3} \mathrm{O}_{8}$ particles. ${ }^{[4,5]} \mathrm{A}$ Kissinger plot of $T_{\mathrm{c}}$ in the differential thermal analysis (DTA) of $x \mathrm{~K}_{2} \mathrm{O}$ . $10 \mathrm{Fe}_{2} \mathrm{O}_{3} \cdot(90-x) \mathrm{V}_{2} \mathrm{O}_{5}$ glasses $(x=20-35)$ showed that the crystallization was triggered by the cleavage of $\mathrm{Fe}^{\text {IIII-O }}$ bonds forming distorted $\mathrm{FeO}_{4}$ tetrahedra with the $\mathrm{Fe}^{\mathrm{III}}-\mathrm{O}$ bond energy of $2.6 \mathrm{eV}$. These experimental results suggested that the crystallization of glass (precipitation of crystalline particles or phase in the glassy phase) was not related to the increase in $\sigma$, but to the structural relaxation. It was noted that $\rho$ was decreased to the order of "kilo" $\Omega$ $\mathrm{cm}$ in $25 \mathrm{~K}_{2} \mathrm{O} \cdot 10 \mathrm{Fe}_{2} \mathrm{O}_{3} \cdot 65 \mathrm{~V}_{2} \mathrm{O}_{5}$ glass consisting of a pseudo-1D network structure. ${ }^{[6-8]}$ It was also noted that the "pathway" of conduction was restricted to the pseudo-1D direction.

Barium, magnesium and phosphorus vanadate glasses have $3 D$-network structures. ${ }^{[8,9]}$ Fukuda et al. investigated $15 \mathrm{BaO} \cdot 15 \mathrm{Fe}_{2} \mathrm{O}_{3} \cdot 70 \mathrm{~V}_{2} \mathrm{O}_{5}$ glass (composition in $\mathrm{mol} \%$ ) in order to seek the higher possibility of "pathway" for the small polaron hopping. ${ }^{[10]}$ Increase in the values of $\sigma$ from $1 \times 10^{-7} \mathrm{~S} \mathrm{~cm}^{-1}$ to $4 \times 10^{-3} \mathrm{~S} \mathrm{~cm}^{-1}(\rho=250 \Omega \mathrm{cm})$ and to $4 \times 10^{-2} \mathrm{~S} \mathrm{~cm}^{-1}(\rho=25 \Omega \mathrm{cm})$ were seen when this glass was annealed at $370{ }^{\circ} \mathrm{C}$ for $120 \mathrm{~min}$ and at $460{ }^{\circ} \mathrm{C}$ for $30 \mathrm{~min}$, respectively. These annealing temperatures were based on $T_{\mathrm{c}}(1)$ of $372{ }^{\circ} \mathrm{C}$ and $T_{\mathrm{c}}(2)$ of $468^{\circ} \mathrm{C}$, which were appropriate for the precipitation of different crystalline particles.
Heat treatment of $20 \mathrm{BaO} \cdot 10 \mathrm{Fe}_{2} \mathrm{O}_{3} \cdot 70 \mathrm{~V}_{2} \mathrm{O}_{5}$ glass (composition in mol\%) for $60 \mathrm{~min}$ at $500^{\circ} \mathrm{C}$, a temperature higher than $T_{\mathrm{g}}$ of $312^{\circ} \mathrm{C}, T_{\mathrm{c}}(1)$ of $376^{\circ} \mathrm{C}$ and $T_{\mathrm{c}}(2)$ of $468{ }^{\circ} \mathrm{C}$, resulted in an enhancement of $\sigma$ from $2.8 \times 10^{-6}$ to $4.3 \times$ $10^{-2} \mathrm{~S} \mathrm{~cm}^{-1}$. ${ }^{[11,12]} \mathrm{After}$ the heat treatment at $500^{\circ} \mathrm{C}$ for 1000 min, $20 \mathrm{BaO} \cdot 10 \mathrm{Fe}_{2} \mathrm{O}_{3} \cdot 70 \mathrm{~V}_{2} \mathrm{O}_{5}$ glass showed an increase in $\sigma$ from $1.6 \times 10^{-5} \mathrm{~S} \mathrm{~cm}^{-1}$ to $1.1 \mathrm{~S} \mathrm{~cm}^{-1}$. ${ }^{[13]} \mathrm{X}$-ray diffraction (XRD) study of $20 \mathrm{BaO} \cdot 10 \mathrm{Fe}_{2} \mathrm{O}_{3} \cdot 70 \mathrm{~V}_{2} \mathrm{O}_{5}$ glass, annealed at $450{ }^{\circ} \mathrm{C}$ for $2000 \mathrm{~min}$, showed precipitates of small amounts of $\mathrm{BaFe}_{2} \mathrm{O}_{4}$ and $\mathrm{BaV}_{2} \mathrm{O}_{6}$ particles of which crystalline growth became pronounced at $T_{\mathrm{c}}(1)$ and $T_{\mathrm{c}}(2)$, respectively. ${ }^{[11,12]}$ Since the Fe ${ }^{\mathrm{III}}-\mathrm{O}$ bond energy $(2.6 \mathrm{eV})^{[14]}$ was smaller than the $\mathrm{V}^{\mathrm{V}}-\mathrm{O}$ bond energy $(3.9-4.9 \mathrm{eV}),{ }^{[14]}$ formation of $\mathrm{BaFe}_{2} \mathrm{O}_{4}$ would proceed to that of $\mathrm{BaV}_{2} \mathrm{O}_{6}$ particles. When $20 \mathrm{BaO} \cdot 10 \mathrm{Fe}_{2} \mathrm{O}_{3} \cdot 70 \mathrm{~V}_{2} \mathrm{O}_{5}$ glass and $x \mathrm{R}_{2} \mathrm{O} \cdot 10$ $\mathrm{Fe}_{2} \mathrm{O}_{3} \cdot(90-x) \mathrm{V}_{2} \mathrm{O}_{5}$ glasses $(\mathrm{R}=\mathrm{Li}, \mathrm{Na}, \mathrm{K} ; x=20,40)$ were annealed at $500{ }^{\circ} \mathrm{C}$ for $1000 \mathrm{~min}$, precipitation of $\mathrm{FeVO}_{4}$ particles was observed. ${ }^{[15]}$ Kubuki et al. suggested that the isothermal annealing of alkaline iron vanadate glasses $\left(x \mathrm{R}_{2} \mathrm{O}\right.$. $\left.10 \mathrm{Fe}_{2} \mathrm{O}_{3} \cdot(90-x) \mathrm{V}_{2} \mathrm{O}_{5}\right)$ at temperatures higher than $450{ }^{\circ} \mathrm{C}$ was not appropriate because $\mathrm{FeVO}_{4}$ had $\sigma$ of $6.7 \times 10^{-7} \mathrm{~S}$ $\mathrm{cm}^{-1}$, which was lower than that of the highly conductive vanadate glass. ${ }^{[15]}$ It was noticed that $25 \mathrm{~K}_{2} \mathrm{O} \cdot 10 \mathrm{Fe}_{2} \mathrm{O}_{3} \cdot 65$ $\mathrm{V}_{2} \mathrm{O}_{5}$ glass showed precipitation of "insulating" $\mathrm{KV}_{3} \mathrm{O}_{8}$ phase after isothermal annealing at $380{ }^{\circ} \mathrm{C}$ for more than 150 min. ${ }^{[4,5]}$ Simultaneously, a decrease in $\sigma$ was observed. These experimental results suggest that the increase in $\sigma$ from $1.6 \times 10^{-5} \mathrm{~S} \mathrm{~cm}^{-1}$ to $1.1 \mathrm{~S} \mathrm{~cm}^{-1}$, recorded in $20 \mathrm{BaO} \cdot 10$ $\mathrm{Fe}_{2} \mathrm{O}_{3} \cdot 70 \mathrm{~V}_{2} \mathrm{O}_{5}$ glass after annealing at $500{ }^{\circ} \mathrm{C}$ for 1000 min, ${ }^{[13]}$ was not due to the crystallization of the glass (formation of glass-ceramic), but to the structural relaxation of the glass network, observed in several vanadate glasses. $[4,5,10-13,15-17]$

In the case of $20 \mathrm{BaO} \cdot 10 \mathrm{Fe}_{2} \mathrm{O}_{3} \cdot 70 \mathrm{~V}_{2} \mathrm{O}_{5}$ glass, activation energy for the electrical conduction $\left(E_{\mathrm{a}}\right)$ showed a decrease from $0.38 \mathrm{eV}$ to $0.13 \mathrm{eV}$ when annealed at $500{ }^{\circ} \mathrm{C}$ for 60 min. ${ }^{[12]}$ As described above, this glass showed a marked increase of $\sigma$ from $2.8 \times 10^{-6}$ to $4.3 \times 10^{-2} \mathrm{~S}$ $\mathrm{cm}^{-1} .{ }^{[11,12]}$ These experimental results indicate that the lessdistorted 3D-network is more effective for fabricating highly conductive vanadate glass than less-distorted pseudo-1D network. On the basis of the discussion above, conductivity of highly conductive vanadate glass could be easily "tuned" by changing the temperature and the time of annealing.

$20 \mathrm{BaO} \cdot 10 \mathrm{Fe}_{2} \mathrm{O}_{3} \cdot x W_{3} \cdot(70-x) \mathrm{V}_{2} \mathrm{O}_{5}$ glasses $(x=10-50)$ were prepared in order to enhance the waterand chemical-durability of $20 \mathrm{BaO} \cdot 10 \mathrm{Fe}_{2} \mathrm{O}_{3} \cdot 70 \mathrm{~V}_{2} \mathrm{O}_{5}$ glass. ${ }^{[16]} \mathrm{XRD}$ study of these glasses showed precipitation of crystalline particles like $\mathrm{FeVO}_{4}, \mathrm{BaFe}_{2} \mathrm{O}_{4}, \mathrm{BaFe}_{12} \mathrm{O}_{19}$ and $\alpha$ $\mathrm{Fe}_{2} \mathrm{O}_{3}$, depending on the composition and the annealing temperature ${ }^{[17]}$ These crystalline particles were not in 
volved with the marked increase of $\sigma$ values, recorded in the highly conductive vanadate glass. A Kissinger plot in the DTA study for $20 \mathrm{BaO} \cdot 10 \mathrm{Fe}_{2} \mathrm{O}_{3} \cdot x W_{3} \cdot(70-x) \mathrm{V}_{2} \mathrm{O}_{5}$ glasses revealed that the crystallization was triggered by the cleavage of $\mathrm{Fe}^{\mathrm{III}}-\mathrm{O}$ bonds having bond energy of $2.6 \mathrm{eV}$.[17] This was also reported for $25 \mathrm{~K}_{2} \mathrm{O} \cdot 10 \mathrm{Fe}_{2} \mathrm{O}_{3}$. $65 \mathrm{~V}_{2} \mathrm{O}_{5}$ glass. ${ }^{[4]}$

Mössbauer spectroscopy has become a very powerful tool for studying the local structure of oxide glass, since Mössbauer nuclides like ${ }^{57} \mathrm{Fe}$ and ${ }^{119} \mathrm{Sn}$ could be easily incorporated into oxide glasses as a probe..$^{[1,2,4-13,15-25]}$ We could determine whether Fe"ll atoms occupied NWF or NWM sites in oxide glasses like silicates, borate, borosilicate, aluminates, tellurite and gallate glasses by plotting the $T_{\mathrm{g}}$ values (ca. $180-770^{\circ} \mathrm{C}$ ) against the $\Delta$ of Fe ${ }^{\mathrm{III}}$ (ca. $0.4-1.3 \mathrm{~mm}$ $\left.\mathrm{s}^{-1}\right) \cdot{ }^{[5,13,16,18-21]}$ A slope of the straight line, obtained from the $T_{\mathrm{g}}$ vs. $\Delta$ plot, was $680 \mathrm{~K}\left(\mathrm{~mm} \mathrm{~s}^{-1}\right)^{-1}$ when Fe ${ }^{\text {III }}$ atoms occupied tetrahedral NWF sites. ${ }^{[18,19]}$ However, the slope

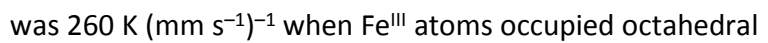
NWF sites, as in tungstate glass. ${ }^{[21]}$ Significantly, the slope

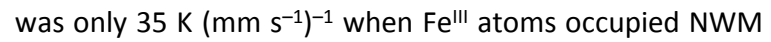
sites, as in phosphate glasses. ${ }^{[18,19]}$ A calibration plot of $T_{\mathrm{g}}$ vs. $\Delta$ was very useful when we characterized unknown glass samples because the structural role of $\mathrm{Fe}^{\text {III }}$ atoms could be easily known. For example, a $T_{\mathrm{g}}$ vs. $\Delta$ plot for 20 $\mathrm{BaO} \cdot 10 \mathrm{Fe}_{2} \mathrm{O}_{3} \cdot x W \mathrm{O}_{3} \cdot(70-x) \mathrm{V}_{2} \mathrm{O}_{5}$ glasses $(x=10-50)$ yielded a slope of $680 \mathrm{~K}\left(\mathrm{~mm} \mathrm{~s}^{-1}\right)^{-1}$,[16] reflecting that Fe ${ }^{\text {III }}$ atoms occupied only tetrahedral NWF sites. It means that they substituted $\mathrm{V}^{\mathrm{IV}}$ or $\mathrm{V}^{\mathrm{V}}$ atoms, ${ }^{[18,19]}$ not octahedral $\mathrm{W}^{\mathrm{VI}}$ sites observed in tungstate glass. ${ }^{[21]}$

Isomer shift $(\delta)$ provides chemical information like oxidation number, coordination number and electronic structure of the Mössbauer atoms. Magnetic information is available from the internal magnetic field $\left(H_{\text {int }}\right)$. The linewidth $(\Gamma)$ offers useful information on the uniformity of the structural units in the materials of interest, i.e., whether or not they are homogeneously distributed in the material or whether the material is crystalline or glassy. ${ }^{[18]}$ Magnitude of $\Gamma$ also gives information on the degree of crystallization of glass, i.e., estimation of the crystalline phase and particles precipitated in the glass matrix.

Distortion or local symmetry of Mössbauer atoms could be deduced from the magnitude of $\Delta .^{[4-13,15-25]}$ Mössbauer spectrum of heat-treated vanadate glasses $[4,5,10-13,15-$ 17,20,22-25] showed a substantial decrease of $\Delta$ for Fe"lI, indicating a decreased distortion or an increased symmetry of "distorted" Fe"ll $\mathrm{O}_{4}$ tetrahedra. This was also the case for "distorted" $\mathrm{VO}_{4}$ tetrahedra constituting the network of vanadate glass because they were directly bonded to "distorted" $\mathrm{FeO}_{4}$ tetrahedra through corner oxygen atoms. Since high-spin Fell' has an isotropic electron configuration of $3 d^{5}$, the electric field gradient (EFG) caused by valence electrons $\left(e q_{\text {val }}\right)$ is "zero". In such a case, $\Delta$ reflects the EFG, caused by lattice $\left(e q_{\mathrm{lat}}\right)$, i.e., by the steric configuration of oxygen atoms constituting distorted $\mathrm{Fe}^{\mathrm{III}} \mathrm{O}_{4}$ and $\mathrm{VO}_{4}$ tetrahedra. ${ }^{[4-13,15-25]}$ Mössbauer study of heat-treated vanadate glasses indicated that $\sigma$ increased greatly when less-distorted $\mathrm{Fe}^{\mathrm{III}} \mathrm{O}_{4}$ tetrahedra were bonded to less-distorted $\mathrm{VO}_{4}$ tetrahedra. ${ }^{[4,5,10-13,15-17,20,22-25]}$ Presence of Felll atoms having an isotropic symmetric electron configuration of $3 d^{5}$ in the outermost orbital was effective for the marked increase of $\sigma$, possibly due to the utilization of five half-occupied $3 d$ orbitals for accepting the carriers (electrons).

The present paper reviews highly conductive $20 \mathrm{BaO}$ - $x \mathrm{M}_{\mathrm{m}} \mathrm{O}_{\mathrm{n}} \cdot(10-x) \mathrm{Fe}_{2} \mathrm{O}_{3} \cdot 70 \mathrm{~V}_{2} \mathrm{O}_{5}$ glasses $(\mathrm{M}=\mathrm{Cu}, \mathrm{Zn} ; x=5$ $\& 10)$, in which substitution of $\mathrm{Cu}^{\prime \prime}\left(3 d^{9}\right), \mathrm{Cu}^{\prime}\left(3 d^{10}\right)$ and $\mathrm{Zn}$ " $\left(3 d^{10}\right)$ for Fe $\mathrm{Fe}^{\text {III }}\left(3 d^{5}\right)$ was investigated focusing on the jump of the conductivity. These highly conductive vanadate glasses were prepared by heat treatment at $450{ }^{\circ} \mathrm{C}$, a given temperature sufficiently higher than the $T_{\mathrm{g}}$ and $T_{\mathrm{c}}$. Conduction mechanism for $\mathrm{ZnO}$-substituted vanadate glass was discussed in conjunction with $\mathrm{CuO}$ - and $\mathrm{Cu}_{2} \mathrm{O}$-substituted vanadate glasses. ${ }^{[22]}$

\section{EXPERIMENTAL}

$20 \mathrm{BaO} \cdot x \mathrm{M}_{\mathrm{m}} \mathrm{O}_{\mathrm{n}} \cdot(10-x) \mathrm{Fe}_{2} \mathrm{O}_{3} \cdot 70 \mathrm{~V}_{2} \mathrm{O}_{5}$ glasses $(\mathrm{M}=\mathrm{Cu}$, $\mathrm{Zn} ; x=0,5,10)$ were prepared by a conventional meltquenching method with $\mathrm{BaCO}_{3}, \mathrm{CuO}, \mathrm{Cu}_{2} \mathrm{O}, \mathrm{ZnO}, \mathrm{Fe}_{2} \mathrm{O}_{3}$ and $\mathrm{V}_{2} \mathrm{O}_{5}$ of guaranteed reagent grade. Each reagent mixture placed in a platinum crucible or an alumina crucible was melted at $1100{ }^{\circ} \mathrm{C}$ for $2 \mathrm{~h}$ in the air using an electric muffle furnace. Homogeneous glass samples of almost black color were prepared by quenching the melt with ice-cold water or with air. Annealing of as-quenched glass sample was also carried out in an electric furnace. DTA study was conducted at a heating rate of $10 \mathrm{~K} \mathrm{~min}^{-1}$ from $R T$ to $600{ }^{\circ} \mathrm{C}$ under $\mathrm{N}_{2}$ atmosphere. Powder of $\alpha-\mathrm{Al}_{2} \mathrm{O}_{3}$ was used as a reference of the temperature. Electrical conductivity $(\sigma)$ was estimated by measuring the resistivity $(\rho)$ of rectangular sample by a conventional DC-four probe method. A linear relationship was obtained by plotting the voltage against the electric current (e.g. $0-10 \mathrm{~mA}$ ) that depended on the magnitude of $\rho$ and the sample size. Mössbauer measurement was made by a constant acceleration method with a source of ${ }^{57} \mathrm{Co}(\mathrm{Rh})$. A foil of $\alpha$-Fe was used as a reference of $\delta$ and also for calibrating the velocity scale of the spectrometer. Software, Mösswinn 3.0i XP, was used for the peak analysis of the Mössbauer spectra.

\section{RESULTS AND DISCUSSION}

A DTA study of $20 \mathrm{BaO} \cdot 5 \mathrm{CuO} \cdot 5 \mathrm{Fe}_{2} \mathrm{O}_{3} \cdot 70 \mathrm{~V}_{2} \mathrm{O}_{5}$ and $20 \mathrm{BaO}$ . $5 \mathrm{Cu}_{2} \mathrm{O} \cdot 5 \mathrm{Fe}_{2} \mathrm{O}_{3} \cdot 70 \mathrm{~V}_{2} \mathrm{O}_{5}$ glasses showed a slight lowering of $T_{\mathrm{g}}$ from 281 to $276-278{ }^{\circ} \mathrm{C}$, compared to $20 \mathrm{BaO} \cdot 10$ $\mathrm{Fe}_{2} \mathrm{O}_{3} \cdot 70 \mathrm{~V}_{2} \mathrm{O}_{5}$ glass. ${ }^{[22]} \mathrm{A}$ lowering of $T_{\mathrm{c}}$ from $373^{\circ} \mathrm{C}$ to 344 
${ }^{\circ} \mathrm{C}$ was also seen in these glasses. In the case of $20 \mathrm{BaO} \cdot 5$ $\mathrm{ZnO} \cdot 5 \mathrm{Fe}_{2} \mathrm{O}_{3} \cdot 70 \mathrm{~V}_{2} \mathrm{O}_{5}$ glass, a lowering of $T_{\mathrm{g}}$ from 307 to $276{ }^{\circ} \mathrm{C}$ was recorded, together with a lowering of $T_{\mathrm{c}}$ from 372 to $345{ }^{\circ} \mathrm{C}$, compared to $20 \mathrm{BaO} \cdot 10 \mathrm{Fe}_{2} \mathrm{O}_{3} \cdot 70 \mathrm{~V}_{2} \mathrm{O}_{5}$ glass. In the case of $20 \mathrm{BaO} \cdot 10 \mathrm{ZnO} \cdot 70 \mathrm{~V}_{2} \mathrm{O}_{5}$ glass, decrease of $T_{\mathrm{g}}$ was observed from 307 to $259^{\circ} \mathrm{C}$, together with a noticeable decrease of $T_{\mathrm{c}}$ from 372 to $304{ }^{\circ} \mathrm{C}$. These DTA results indicate that substitution of $\mathrm{CuO}, \mathrm{Cu}_{2} \mathrm{O}$ and $\mathrm{ZnO}$ for $\mathrm{Fe}_{2} \mathrm{O}_{3}$ in $20 \mathrm{BaO} \cdot 10 \mathrm{Fe}_{2} \mathrm{O}_{3} \cdot 70 \mathrm{~V}_{2} \mathrm{O}_{5}$ glass is effective to fabricate less heat-resistant vanadate glasses with high conductivity. They may have several applications like sensors, electron-emitting needle, conductive glass paste, static electricity protecting material and the hyperfine processing materials combined with FIB (focused ion beam), electrons and laser.

$R T$-conductivities $(\sigma)$ of $20 \mathrm{BaO} \cdot 5 \mathrm{CuO} \cdot 5 \mathrm{Fe}_{2} \mathrm{O}_{3}$. $70 \mathrm{~V}_{2} \mathrm{O}_{5}$ and $20 \mathrm{BaO} \cdot 5 \mathrm{Cu}_{2} \mathrm{O} \cdot 5 \mathrm{Fe}_{2} \mathrm{O}_{3} \cdot 70 \mathrm{~V}_{2} \mathrm{O}_{5}$ glasses, measured after isothermal annealing at $450{ }^{\circ} \mathrm{C}$ for $0-300$ min, are illustrated in Figure 1. ${ }^{[22]}$ It is noteworthy that 30 min-annealing caused an increase of $\sigma$ from $3.9 \times 10^{-6}$ to $3.2 \times 10^{-1} \mathrm{~S} \mathrm{~cm}^{-1}(\rho=3.1 \Omega \mathrm{cm})$ in $20 \mathrm{BaO} \cdot 5 \mathrm{CuO} \cdot 5 \mathrm{Fe}_{2} \mathrm{O}_{3}$. $70 \mathrm{~V}_{2} \mathrm{O}_{5}$ glass $(\Delta)$, and from $5.1 \times 10^{-6}$ to $2.0 \times 10^{-1} \mathrm{~S} \mathrm{~cm}^{-1}(\rho$ $=5.0 \Omega \mathrm{cm}$ ) in $20 \mathrm{BaO} \cdot 5 \mathrm{Cu}_{2} \mathrm{O} \cdot 5 \mathrm{Fe}_{2} \mathrm{O}_{3} \cdot 70 \mathrm{~V}_{2} \mathrm{O}_{5}$ glass ( $\square$ ). These $\sigma$ values are one order of magnitude higher than that of $20 \mathrm{BaO} \cdot 10 \mathrm{Fe}_{2} \mathrm{O}_{3} \cdot 70 \mathrm{~V}_{2} \mathrm{O}_{5}$ glass (0), which had an increase in $\sigma$ from $1.9 \times 10^{-6}$ to $3.4 \times 10^{-2} \mathrm{~S} \mathrm{~cm}^{-1}(\rho=29 \Omega$ $\mathrm{cm})$ under the same annealing condition $\left(450{ }^{\circ} \mathrm{C}, 60 \mathrm{~min}\right)$. Figure 1 indicates that $\sigma$ of $\mathrm{CuO}$ - and $\mathrm{Cu}_{2} \mathrm{O}$-containing vanadate glasses finally converged to $2.8 \times 10^{-1} \mathrm{~S} \mathrm{~cm}^{-1}$ after the annealing at $450{ }^{\circ} \mathrm{C}$. It is likely that $\mathrm{Cu}_{2} \mathrm{O}$ and $\mathrm{CuO}$ had equilibrium in the air. The gradual increase in $\sigma$ from $2.0 \times$ $10^{-1}$ to $2.8 \times 10^{-1} \mathrm{~S} \mathrm{~cm}^{-1}$ observed for $20 \mathrm{BaO} \cdot 5 \mathrm{Cu}_{2} \mathrm{O} \cdot 5$ $\mathrm{Fe}_{2} \mathrm{O}_{3} \cdot 70 \mathrm{~V}_{2} \mathrm{O}_{5}$ glass ( $\square$ ) was ascribed to slow oxidation of $\mathrm{Cu}_{2} \mathrm{O}$ to $\mathrm{CuO}$ during the heat treatment in the air. As mentioned above, the increase of $\sigma$ was observed in $\mathrm{K}_{2} \mathrm{O}$ $\mathrm{Fe}_{2} \mathrm{O}_{3}-\mathrm{V}_{2} \mathrm{O}_{5},{ }^{[4,5]} \mathrm{BaO}-\mathrm{Fe}_{2} \mathrm{O}_{3}-\mathrm{V}_{2} \mathrm{O}_{5}{ }^{[10-13]}$ and $\mathrm{BaO}-\mathrm{Fe}_{2} \mathrm{O}_{3}-\mathrm{WO}_{3}-$ $\mathrm{V}_{2} \mathrm{O}_{5}$ glasses ${ }^{[16,17]}$ after isothermal annealing at temperatures higher than $T_{\mathrm{g}}$ or $T_{\mathrm{c}}$. It is noteworthy that $\sigma$ values of $\mathrm{CuO}$ - and $\mathrm{Cu}_{2} \mathrm{O}$-containing vanadate glasses were one order of magnitude higher than that of $20 \mathrm{BaO} \cdot 10 \mathrm{Fe}_{2} \mathrm{O}_{3} \cdot 70 \mathrm{~V}_{2} \mathrm{O}_{5}$ glass, in spite that they had essentially the same $3 D$-network structure as $20 \mathrm{BaO} \cdot 10 \mathrm{Fe}_{2} \mathrm{O}_{3} \cdot 70 \mathrm{~V}_{2} \mathrm{O}_{5}$ glass. Figure 1 evidently demonstrated that the electron configurations of $3 d^{9}\left(\mathrm{Cu}^{\prime \prime}\right)$ and $3 d^{10}\left(\mathrm{Cu}^{\prime}\right)$ were involved in the high conductivity.

Similar result was recently observed in $20 \mathrm{BaO}$. $5 \mathrm{ZnO} \cdot 5 \mathrm{Fe}_{2} \mathrm{O}_{3} \cdot 70 \mathrm{~V}_{2} \mathrm{O}_{5}$ glass (Figure 2), which shows that $R T$-conductivity $(\sigma)$ increased from $2.5 \times 10^{-6} \mathrm{~S} \mathrm{~cm}^{-1}$ to 2.1 $\times 10^{-1} \mathrm{~S} \mathrm{~cm}^{-1}$ after isothermal annealing at $450^{\circ} \mathrm{C}$ for $30 \mathrm{~min}$ $(\bullet)$. The latter conductivity was larger than that of $20 \mathrm{BaO}$. $10 \mathrm{Fe}_{2} \mathrm{O}_{3} \cdot 70 \mathrm{~V}_{2} \mathrm{O}_{5}$ glass $\left(3.4 \times 10^{-2} \mathrm{~S} \mathrm{~cm}^{-1}\right)$. This result further provides the evidence that substitution of $\mathrm{ZnO}$ for $\mathrm{Fe}_{2} \mathrm{O}_{3}$ is quite effective in improving the $R T$-conductivity of $\mathrm{BaO}-\mathrm{Fe}_{2} \mathrm{O}_{3}-\mathrm{V}_{2} \mathrm{O}_{5}$ glass. It appears that $3 d^{10}$-configuration of $\mathrm{Zn}$ " contributes to the increase in the conductivity. All the experimental results suggest that $\mathrm{Zn}^{\prime \prime}, \mathrm{Cu}^{\prime}$ and $\mathrm{Cu}^{\prime \prime}$ atoms, having $3 d^{10}$ - or $3 d^{9}$-electron configurations, are quite effective to fabricate highly conductive vanadate glass than the Fe ${ }^{\text {III }}$ atoms having $3 d^{5}$-configuration. ${ }^{[11,12]}$
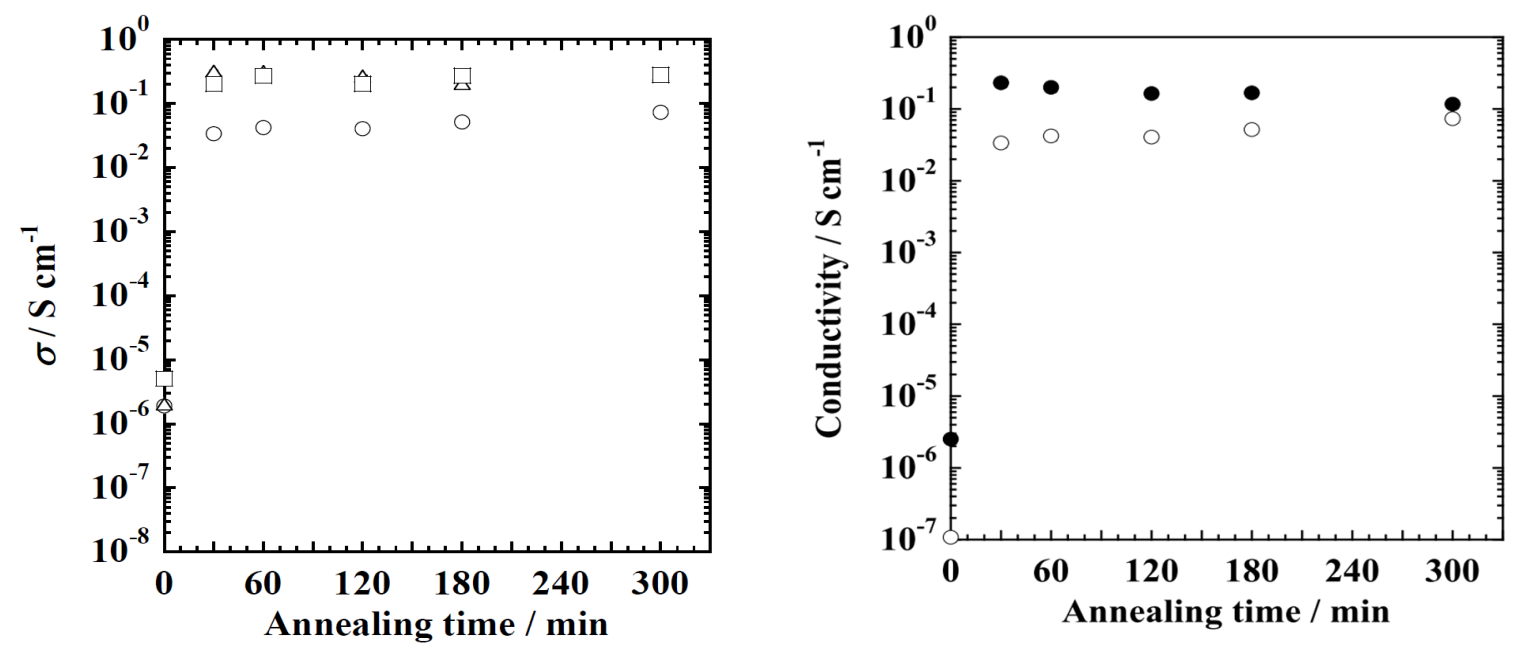

Figure 1. $R T$-conductivity $(\sigma)$ of $20 \mathrm{BaO} \cdot 10 \mathrm{Fe}_{2} \mathrm{O}_{3} \cdot 70 \mathrm{~V}_{2} \mathrm{O}_{5}(\mathrm{o}), 20 \mathrm{BaO} \cdot 5 \mathrm{CuO} \cdot 5 \mathrm{Fe}_{2} \mathrm{O}_{3} \cdot 70 \mathrm{~V}_{2} \mathrm{O}_{5}(\Delta)$ and $20 \mathrm{BaO} \cdot 5 \mathrm{Cu}_{2} \mathrm{O} \cdot 5$ $\mathrm{Fe}_{2} \mathrm{O}_{3} \cdot 70 \mathrm{~V}_{2} \mathrm{O}_{5}$ glasses (ם), measured after isothermal annealing at $450{ }^{\circ} \mathrm{C}[22]$ (left).

Figure 2. RT-conductivity $(\sigma)$ of $20 \mathrm{BaO} \cdot 10 \mathrm{Fe}_{2} \mathrm{O}_{3} \cdot 70 \mathrm{~V}_{2} \mathrm{O}_{5}(0)$ and $20 \mathrm{BaO} \cdot 5 \mathrm{ZnO} \cdot 5 \mathrm{Fe}_{2} \mathrm{O}_{3} \cdot 70 \mathrm{~V}_{2} \mathrm{O}_{5}$ glasses $(\bullet)$, measured after isothermal annealing at $450^{\circ} \mathrm{C}$ (right). 

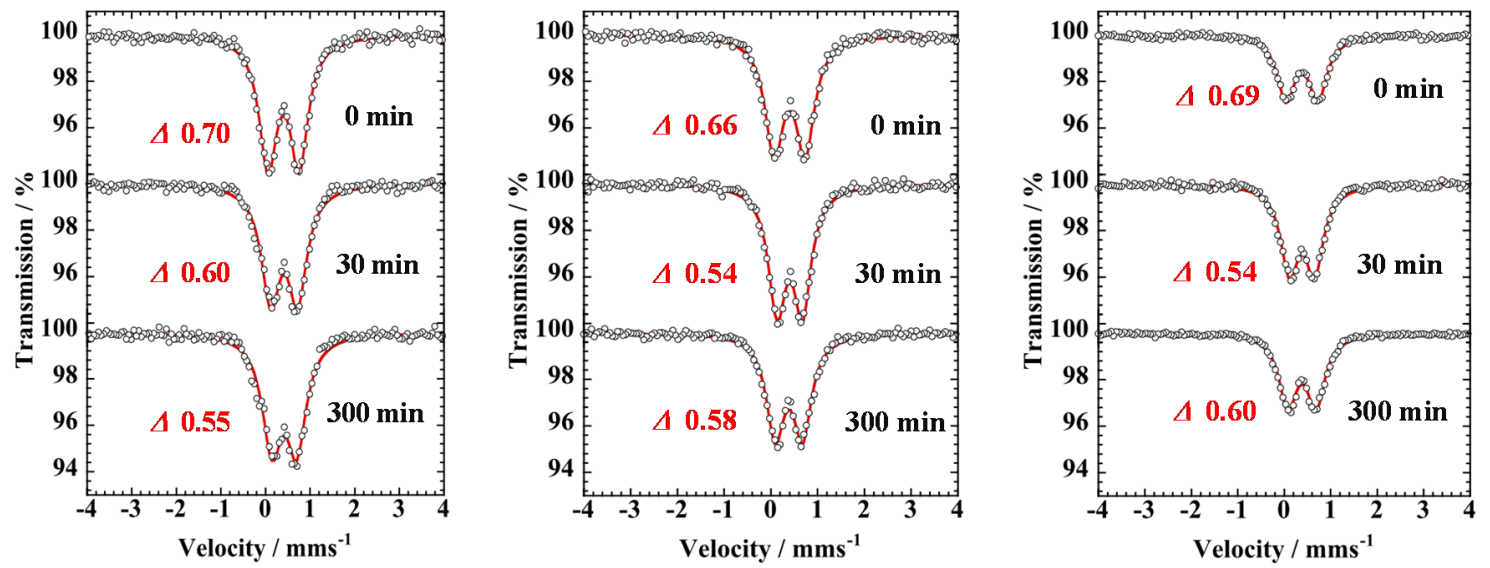

Figure 3. $R T$-Mössbauer spectra of $20 \mathrm{BaO} \cdot 10 \mathrm{Fe}_{2} \mathrm{O}_{3} \cdot 70 \mathrm{~V}_{2} \mathrm{O}_{5}$ (left), $20 \mathrm{BaO} \cdot 5 \mathrm{CuO} \cdot 5 \mathrm{Fe}_{2} \mathrm{O}_{3} \cdot 70 \mathrm{~V}_{2} \mathrm{O}_{5}$ (middle) and $20 \mathrm{BaO} \cdot 5$ $\mathrm{Cu}_{2} \mathrm{O} \cdot 5 \mathrm{Fe}_{2} \mathrm{O}_{3} \cdot 70 \mathrm{~V}_{2} \mathrm{O}_{5}$ glasses (right), measured before and after isothermal annealing at $450{ }^{\circ} \mathrm{C} \cdot{ }^{[22]}$

Figure 3 illustrates $R T$-Mössbauer spectra of $20 \mathrm{BaO}$ - $10 \mathrm{Fe}_{2} \mathrm{O}_{3} \cdot 70 \mathrm{~V}_{2} \mathrm{O}_{5}$ (left), $20 \mathrm{BaO} \cdot 5 \mathrm{CuO} \cdot 5 \mathrm{Fe}_{2} \mathrm{O}_{3} \cdot 70 \mathrm{~V}_{2} \mathrm{O}_{5}$ (middle) and $20 \mathrm{BaO} \cdot 5 \mathrm{Cu}_{2} \mathrm{O} \cdot 5 \mathrm{Fe}_{2} \mathrm{O}_{3} \cdot 70 \mathrm{~V}_{2} \mathrm{O}_{5}$ glasses (right), measured before and after isothermal annealing at $450{ }^{\circ} \mathrm{C} \cdot{ }^{[22]} \mathrm{A}$ marked decrease of $\Delta$ was observed in $20 \mathrm{BaO}$ - $10 \mathrm{Fe}_{2} \mathrm{O}_{3} \cdot 70 \mathrm{~V}_{2} \mathrm{O}_{5}$ glass (left) from 0.70 to $0.55 \mathrm{~mm} \mathrm{~s}^{-1}$ after the annealing at $450{ }^{\circ} \mathrm{C}$ for $300 \mathrm{~min}$. Figure 3 indicates that both $\mathrm{CuO}$ - and $\mathrm{Cu}_{2} \mathrm{O}$-containing vanadate glasses showed a decrease of $\Delta$ by $0.12-0.15 \mathrm{~mm} \mathrm{~s}^{-1}$ after annealing at $450{ }^{\circ} \mathrm{C}$ for only $30 \mathrm{~min}$. Decrease of $\Delta$ was not so large in the case of $20 \mathrm{BaO} \cdot 5 \mathrm{CuO} \cdot 5 \mathrm{Fe}_{2} \mathrm{O}_{3} \cdot 70 \mathrm{~V}_{2} \mathrm{O}_{5}$ (middle) and $20 \mathrm{BaO} \cdot 5 \mathrm{Cu}_{2} \mathrm{O} \cdot 5 \mathrm{Fe}_{2} \mathrm{O}_{3} \cdot 70 \mathrm{~V}_{2} \mathrm{O}_{5}$ glasses (right) after the annealing for $300 \mathrm{~min}$, probably because these glasses included $\mathrm{Cu}$ atoms in addition to Fe and $\mathrm{V}$ atoms. In this case, their complicated networks might be less effectively "relaxed" by the heat treatment.

All the Mössbauer spectra show a noticeable decrease in $\Delta$ values after the heat treatment, suggesting a decreased $e q_{\text {lat }}$ at the nuclear sites of ${ }^{57} \mathrm{Fe}$, and hence a decreased distortion of $\mathrm{FeO}_{4}$ tetrahedra. This is also the case for distorted $\mathrm{VO}_{4}$ tetrahedra, since they are directly bonded to $\mathrm{FeO}_{4}$ tetrahedra through corner oxygen atoms. These Mössbauer results are in good agreement with the marked increase of $\sigma$, observed after 30 min-annealing (see Figure 1).

Figure 4 shows $R T$-Mössbauer spectra of $20 \mathrm{BaO} \cdot 5$ $\mathrm{ZnO} \cdot 5 \mathrm{Fe}_{2} \mathrm{O}_{3} \cdot 70 \mathrm{~V}_{2} \mathrm{O}_{5}$ glass in which a decrease of $\Delta$ was observed from $0.68 \mathrm{~mm} \mathrm{~s}^{-1}$ to 0.61 and to $0.62 \mathrm{~mm} \mathrm{~s}^{-1}$ after isothermal annealing at $450{ }^{\circ} \mathrm{C}$ for 30 and $300 \mathrm{~min}$, respectively. The experimental error of $\Delta$ is estimated to be \pm 0.01 $-0.02 \mathrm{~mm} \mathrm{~s}^{-1}$. The decrease of $\Delta$ is ascribed to a decreased distortion of $\mathrm{FeO}_{4}$ and $\mathrm{VO}_{4}$ tetrahedra which are connected to each other through corner oxygen atoms to form distorted network structure.

Decrease of $\Delta$ value was observed when iron-containing vanadate glass was annealed for several ten minutes or more at temperatures higher than $T_{\mathrm{g}}$ or $T_{\mathrm{c} .}{ }^{[4,5,10-13,15-}$
17,20,22,23] This behavior accompanied, without exception, significant increase or jump of the conductivity by several orders of magnitude, which primarily depended on the annealing temperature. It is interesting to correlate this behavior with the probability of the small polaron hopping, ${ }^{[3]}$ which has successfully been utilized to understand the conduction mechanism of semiconducting vanadate glass with $\sigma$ of $\mathrm{ca} .10^{-5}$ to $10^{-7} \mathrm{~S} \mathrm{~cm}^{-1}$. In the early study of $25 \mathrm{~K}_{2} \mathrm{O} \cdot 10$ $\mathrm{Fe}_{2} \mathrm{O}_{3} \cdot 65 \mathrm{~V}_{2} \mathrm{O}_{5}$ glass annealed at $380^{\circ} \mathrm{C}$, as described above, enhancement of $\sigma$ was observed from $6.3 \times 10^{-8} \mathrm{~S}$ $\mathrm{cm}^{-1}\left(\rho=1.6 \times 10^{7} \Omega \mathrm{cm}\right)$ to $4.3 \times 10^{-4} \mathrm{~S} \mathrm{~cm}^{-1}(\rho=2.3 \mathrm{k} \Omega \mathrm{cm})$, which was ascribed to the increased probability of the small polaron hopping in the less-distorted $\mathrm{FeO}_{4}$ and $\mathrm{VO}_{4}$ tetrahedra. ${ }^{[4,5]}$

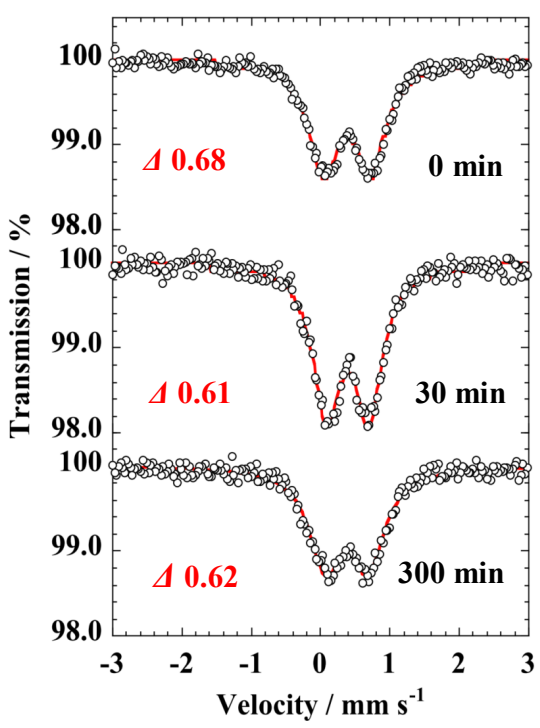

Figure 4. RT-Mössbauer spectra of $20 \mathrm{BaO} \cdot 5 \mathrm{ZnO} \cdot 5 \mathrm{Fe}_{2} \mathrm{O}_{3}$. $70 \mathrm{~V}_{2} \mathrm{O}_{5}$ glass, measured before and after isothermal annealing at $450{ }^{\circ} \mathrm{C}$. 
In such a case, 3d-orbitals of Fe $\mathrm{III}^{\mathrm{II}} \mathrm{V}^{\mathrm{IV}}$ and $\mathrm{V}^{\mathrm{V}}$ atoms would be effectively overlapped with the $2 p$-orbitals of oxygen atoms. It was concluded that less-distorted $\mathrm{FeO}_{4}$ and $\mathrm{VO}_{4}$ tetrahedra were favorable for the small polaron hopping from $\mathrm{V}^{\mathrm{IV}}$ to $\mathrm{V}^{\mathrm{V}}$ and Fe $\mathrm{F}^{\mathrm{II}}$ via oxygen atoms sharing $\mathrm{VO}_{4}$ and $\mathrm{FeO}_{4}$ tetrahedra. It was considered that the presence of Fe"ll atoms, which have symmetric electron configuration of $3 d^{5}$, was favorable for the small polaron hopping from $V^{\mathrm{IV}}$ to $\mathrm{V}^{\mathrm{V}}$ and Fe ${ }^{\text {III }}$ via oxygen atoms. ${ }^{[4,5]}$ All the Mössbauer results indicate that the structural relaxation of the glass network was well reflected as a decrease of $\Delta . .^{[4-5,10-13,15-}$ 17,20,22,23] The small polaron hopping will be promoted as the structural relaxation of the network goes on.

If the electrical conduction of highly conductive vanadate glass with $\sigma$ higher than $c a .10^{-4} \mathrm{~S} \mathrm{~cm}^{-1}$ were due to the structural relaxation of the network, increase in the $\sigma$ value would be directly proportional to the decrease of $\Delta$ value. Mössbauer spectra revealed that the decrease of $\Delta$ was the most remarkable in the case of $20 \mathrm{BaO} \cdot 10 \mathrm{Fe}_{2} \mathrm{O}_{3}$. $70 \mathrm{~V}_{2} \mathrm{O}_{5}$ glass (Figure 3, left), while $\mathrm{CuO}-, \mathrm{Cu}_{2} \mathrm{O}$ - (Figure 3, middle and right) and $\mathrm{ZnO}$-containing vanadate glasses (Figure 4) showed smaller decreases. Nevertheless, $\sigma$ of the latter group was one order of magnitude larger than that of the former (see Figures 1 and 2). These results suggested that alternative mechanism to the small polaron hopping was necessary to explain the conduction behavior of highly conductive vanadate glasses. ${ }^{[4-5,10-13,15-17,20,22,23]}$

This authors' group introduced $n$-type semiconductor model to the conduction mechanism in conjunction with the small polaron hopping theory, because the carrier of vanadate glass was the valence electrons originating from $\mathrm{V}^{\mathrm{IV}}$ atoms with $3 d^{1}$-electron configuration. ${ }^{[12]}$ In the case of $20 \mathrm{BaO} \cdot 10 \mathrm{Fe}_{2} \mathrm{O}_{3} \cdot 70 \mathrm{~V}_{2} \mathrm{O}_{5}$ glass, activation energy for the conduction $\left(E_{\mathrm{a}}\right)$ was calculated from the $\sigma$ values obtained at different temperatures $(T)$ between $R T$ and $100^{\circ} \mathrm{C} .{ }^{[12]}$ For the calculation of $E_{\mathrm{a}}$, the small polaron hopping equation ${ }^{[3]}$ was used instead of the Arrhenius equation;

$$
\sigma T=A \exp \left(-E_{a} / k T\right)
$$

where $T$ and $k$ are the measuring temperature $(\mathrm{K})$ and the Boltzmann constant, respectively. Conductivity $(\sigma)$ of $20 \mathrm{BaO} \cdot 10 \mathrm{Fe}_{2} \mathrm{O}_{3} \cdot 70 \mathrm{~V}_{2} \mathrm{O}_{5}$ glass increased with an increasing temperature. ${ }^{[12]}$ Natural logarithms of $\sigma T$ plotted against the reciprocal of the measuring temperature $(T)$ showed a linear relationship with different slopes, which depended on the temperature and the time period of the isothermal annealing. ${ }^{[12]}$ Activation energies $\left(E_{\mathrm{a}}\right)$ calculated from the slope of the In $\sigma T$ vs. $T^{-1}$ plot are shown in Figure 5 , which indicates that $E_{\mathrm{a}}$ decreases when the annealing temperature is higher than $T_{\mathrm{c}}$ and when the annealing time is long. Figure 5 evidences that $\sigma$ was linearly increased with

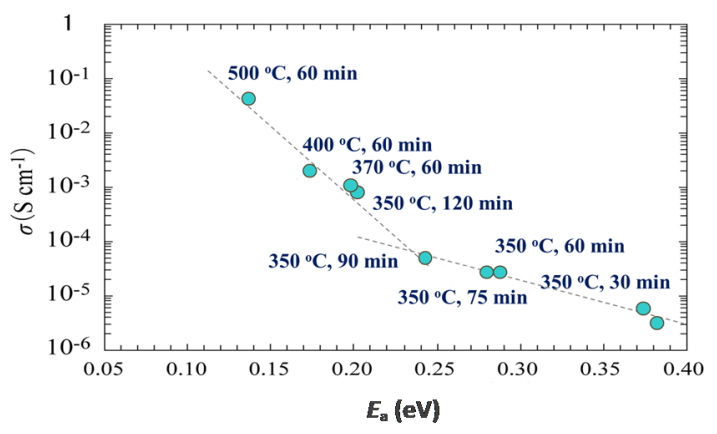

Figure 5. A relationship between the electrical conductivity $(\sigma)$ and the activation energy $\left(E_{\mathrm{a}}\right)$ estimated for $20 \mathrm{BaO}$. $10 \mathrm{Fe}_{2} \mathrm{O}_{3} \cdot 70 \mathrm{~V}_{2} \mathrm{O}_{5}$ glass after isothermal annealing. ${ }^{12]}$

decreasing value of $E_{\mathrm{a}}$. The plot is composed of two components: one relationship obtained after isothermal annealing at $350{ }^{\circ} \mathrm{C}$ and the other obtained after the isothermal annealing conducted at temperatures of $350-500^{\circ} \mathrm{C}$. The increase of $\sigma$ was promoted by the annealing at higher temperatures probably because the glass network was significantly cleaved to induce recombination of the fragments for the "partial" crystallization or precipitation of crystalline particles. In the case of as-quenched $20 \mathrm{BaO} \cdot 10 \mathrm{Fe}_{2} \mathrm{O}_{3} \cdot 70$ $\mathrm{V}_{2} \mathrm{O}_{5}$ glass with $\sigma$ of $2.8 \times 10^{-6} \mathrm{~S} \mathrm{~cm}^{-1}, E_{\mathrm{a}}$ was calculated as $0.38 \mathrm{eV}$, whereas it decreased to $0.13 \mathrm{eV}\left(\sigma=4.3 \times 10^{-2}\right.$ $\mathrm{S} \mathrm{cm}^{-1}$ ) after the annealing at $500{ }^{\circ} \mathrm{C}$ for $60 \mathrm{~min} .{ }^{[12]}$

As shown in Figure 1, $20 \mathrm{BaO} \cdot 5 \mathrm{CuO} \cdot 5 \mathrm{Fe}_{2} \mathrm{O}_{3}$. $70 \mathrm{~V}_{2} \mathrm{O}_{5}$ glass showed $\sigma$ of $3.2 \times 10^{-1} \mathrm{~S} \mathrm{~cm}^{-1}$ after isothermal annealing at $450{ }^{\circ} \mathrm{C}$ for $30 \mathrm{~min}$, while $20 \mathrm{BaO} \cdot 5 \mathrm{Cu}_{2} \mathrm{O} \cdot 5$ $\mathrm{Fe}_{2} \mathrm{O}_{3} \cdot 70 \mathrm{~V}_{2} \mathrm{O}_{5}$ glass had $\sigma$ of $2.0 \times 10^{-1} \mathrm{~S} \mathrm{~cm}^{-1}$. Both glasses showed identical $\sigma$ value of $2.8 \times 10^{-1} \mathrm{~S} \mathrm{~cm}^{-1}$ after annealing at $450{ }^{\circ} \mathrm{C}$ for $300 \mathrm{~min}$. It was noted that $E_{\mathrm{a}}$ 's of copper-containing vanadate glasses annealed at $450^{\circ} \mathrm{C}$ for 60 min were $0.09-0.10 \mathrm{eV}$, ${ }^{[22]}$ smaller than that of $20 \mathrm{BaO} \cdot 10 \mathrm{Fe}_{2} \mathrm{O}_{3}$. $70 \mathrm{~V}_{2} \mathrm{O}_{5}$ glass $(0.13 \mathrm{eV})$ in which $\sigma$ was reported to be $3.4 \times$ $10^{-2} \mathrm{~S} \mathrm{~cm}^{-1}$ after the same annealing. Conductivities of $\mathrm{Li}^{+}-$ and $\mathrm{Na}^{+}$-containing iron vanadate glasses, measured after the isothermal annealing at $400-450^{\circ} \mathrm{C}$ for $100 \mathrm{~min}$, were respectively estimated to be $1.0 \times 10^{-1}$ and $2.6 \times 10^{-2} \mathrm{~S} \mathrm{~cm}^{-1}$, together with the $E_{\mathrm{a}}$ 's of 0.10 and $0.13 \mathrm{eV} .{ }^{[15]}$ Alkaline iron tungsten vanadate glasses showed $\sigma$ values of $6.2 \times 10^{-4}-$ $4.5 \times 10^{-3} \mathrm{~S} \mathrm{~cm}^{-1}$ and $E_{\mathrm{a}}$ 's of $0.15-0.21 \mathrm{eV} .{ }^{[20]}$ Barium iron manganese vanadate glasses exhibited $\sigma$ of $1.4 \times 10^{-2} \mathrm{~S} \mathrm{~cm}^{-1}$ after annealing at $500{ }^{\circ} \mathrm{C}$ for $1000 \mathrm{~min}$, and the $E_{\mathrm{a}}$ was calculated as $0.11 \mathrm{eV} .{ }^{[23]}$ These results suggest that the conductivity of highly conductive vanadate glasses, prepared by the annealing at temperatures higher than $T_{\mathrm{g}}$, favorably at temperatures higher than $T_{c}$, is closely related to the magnitude of $E_{\mathrm{a}}$.

These $E_{\mathrm{a}}$ values are significantly smaller than the band gap $(\triangle E)$ between the valence band $(\mathrm{VB})$ and the conduction band $(C B)$, reported for typical semiconductors like 
GaSb (0.23 eV), Ge (0.68 eV) and Si (1.16 eV). ${ }^{[12]}$ A photoluminescence study of $20 \mathrm{BaO} \cdot 10 \mathrm{Fe}_{2} \mathrm{O}_{3} \cdot 70 \mathrm{~V}_{2} \mathrm{O}_{5}$ glass annealed at $500^{\circ} \mathrm{C}$ for $60 \mathrm{~min}$ showed the $\Delta E$ of $2.25 \mathrm{eV}$. $\Delta E$ of as-quenched vanadate glass was too large to be estimated. Figure 6 is a schematic view of $20 \mathrm{BaO} \cdot 10 \mathrm{Fe}_{2} \mathrm{O}_{3} \cdot 70 \mathrm{~V}_{2} \mathrm{O}_{5}$ glass in which $E_{\mathrm{a}}$ was correlated to the energy difference between the donor level and the $C B$, since it was much smaller than the band gap $(\Delta E)$. As described above, a decrease of $E_{\mathrm{a}}$ was recorded from 0.38 to $0.13 \mathrm{eV}$ in $20 \mathrm{BaO}$. $10 \mathrm{Fe}_{2} \mathrm{O}_{3} \cdot 70 \mathrm{~V}_{2} \mathrm{O}_{5}$ glass after the isothermal annealing at $500{ }^{\circ} \mathrm{C}$ for 60 min. ${ }^{[12]}$ Carrier (electron) density in the $\mathrm{CB}$ would increase along with a decrease of the energy gap between the donor level and the $\mathrm{CB}$, hence giving high possibility of producing highly conductive vanadate glass.

Electron configurations of $3 d^{10}$ and $3 d^{9}$ in $\mathrm{Zn} n^{11}, \mathrm{Cu}$ and $\mathrm{Cu}^{\prime l}$ cause the valence electrons to occupy the $\mathrm{CB}$, which is primarily composed of anti-bonding $4 s$-orbitals. This will result in an increase in the carrier density of the $C B$ and hence an increase in the electrical conductivity. In such a case, shielding of nuclear charge by nine or ten $3 d$-electrons will be effective for the "smooth" carrier (electron) flow in the $\mathrm{CB}$. Figures 1 and 2 indicate that the number of $3 d$-electrons was closely related to the highly conductive vanadate glass. If the $3 d$-orbitals were almost or fully occupied, valence electrons originating from VIV $\left(3 d^{1}\right)$ would occupy the $C B$ primarily composed of anti-bonding $4 s$-orbitals. Figures 1 and 2 indicate that the transition metal oxides having $3 d^{10}$ and $3 d^{9}$-configurations are favorable for the fabrication of highly conductive vanadate glass. Substitution of " $3 d$-block elements" having the electron configurations of $3 d^{10}\left(\mathrm{Cu}^{\prime}\right.$, $\mathrm{Zn}$ ") and $3 d^{9}\left(\mathrm{Cu}^{\prime \prime}\right)$ for $3 d^{5}$ (Fe $\mathrm{Fe}^{\text {III }}$ ) is very effective, as $20 \mathrm{BaO}$. $5 \mathrm{ZnO} \cdot 5 \mathrm{Fe}_{2} \mathrm{O}_{3} \cdot 70 \mathrm{~V}_{2} \mathrm{O}_{5}$ glass annealed at $450{ }^{\circ} \mathrm{C}$ for $30 \mathrm{~min}$ proved a marked increase of $\sigma$ from $2.5 \times 10^{-6} \mathrm{~S} \mathrm{~cm}^{-1}$ to $2.1 \times$ $10^{-1} \mathrm{~S} \mathrm{~cm}^{-1}$, one order of magnitude larger than that of 20 $\mathrm{BaO} \cdot 10 \mathrm{Fe}_{2} \mathrm{O}_{3} \cdot 70 \mathrm{~V}_{2} \mathrm{O}_{5}$ glass $\left(3.4 \times 10^{-2} \mathrm{~S} \mathrm{~cm}^{-1}\right)$. This was also the case for $20 \mathrm{BaO} \cdot 5 \mathrm{CuO} \cdot 5 \mathrm{Fe}_{2} \mathrm{O}_{3} \cdot 70 \mathrm{~V}_{2} \mathrm{O}_{5}$ and $20 \mathrm{BaO} \cdot 5 \mathrm{Cu}_{2} \mathrm{O} \cdot 5 \mathrm{Fe}_{2} \mathrm{O}_{3} \cdot 70 \mathrm{~V}_{2} \mathrm{O}_{5}$ glasses of which $\sigma$ values increased from $3.9 \times 10^{-6} \mathrm{~S} \mathrm{~cm}^{-1}$ to $3.2 \times 10^{-1} \mathrm{~S} \mathrm{~cm}^{-1}$ and from $5.1 \times 10^{-6} \mathrm{~S} \mathrm{~cm}^{-1}$ to $2.0 \times 10^{-1} \mathrm{~S} \mathrm{~cm}^{-1}$, respectively, by the isothermal annealing at $450{ }^{\circ} \mathrm{C}$ for $30 \mathrm{~min} .{ }^{[22]}$ All the experimental results for several vanadate glasses ${ }^{[4-5,10-13,15-}$ 17,20,22,23] demonstrated that decrease of $E_{\mathrm{a}}$ accompanied an increase of carrier (electron) density in the $\mathrm{CB}$, and the formation of highly conductive vanadate glasses. In other words, n-type semiconductor model is predominant over the small polaron hopping, which has been generally utilized to carry out the conduction mechanism of "semiconducting" vanadate glass with resistivity of "mega" $\Omega \mathrm{cm}$.

Silver- or lithium-ion containing iron vanadate glass exhibited ionic conduction due to mobile $\mathrm{Ag}^{+}$and $\mathrm{Li}^{+}$ ions $^{[15,24-28]}$ in addition to the electronic conduction described above. Mössbauer and DTA study of $40 \mathrm{Agl} \cdot x \mathrm{Ag}_{2} \mathrm{O}$ $\cdot(59-x) \mathrm{V}_{2} \mathrm{O}_{5} \cdot \mathrm{Fe}_{2} \mathrm{O}_{3}$ and $x \mathrm{Ag}_{2} \mathrm{O} \cdot(90-x) \mathrm{V}_{2} \mathrm{O}_{5} \cdot 10 \mathrm{Fe}_{2} \mathrm{O}_{3}$

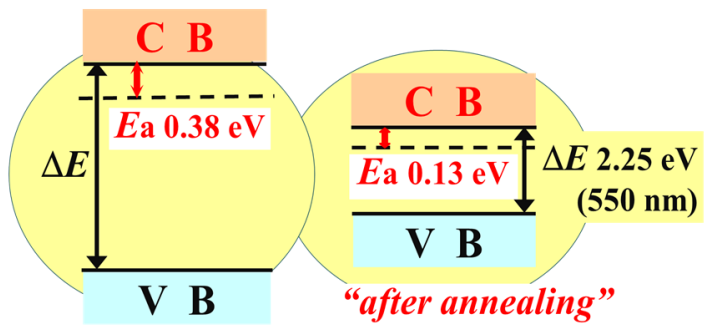

Figure 6. Schematic image of the energy level for $20 \mathrm{BaO}$. $10 \mathrm{Fe}_{2} \mathrm{O}_{3} \cdot 70 \mathrm{~V}_{2} \mathrm{O}_{5}$ glass before and after the isothermal annealing conducted at $500{ }^{\circ} \mathrm{C}$ for $60 \mathrm{~min}$.

glasses revealed that the structural change caused by $\mathrm{Ag}_{2} \mathrm{O}$ content was essentially the same as that by alkali ions in alkali vanadate glasses. Structural change was confirmed from $2 D$ - to pseudo- $1 D$ with an increasing $\mathrm{Ag}_{2} \mathrm{O}$ content when the $\mathrm{Ag}_{2} \mathrm{O} / \mathrm{V}_{2} \mathrm{O}_{5}$ ratio was less than unity, while the change occurred from pseudo-1D- to $3 D$ when the ratio exceeded unity. ${ }^{[24]}$ Electrical conductivity of "superionic conducting" Agl-containing vanadate glass showed a concordant change with the change of $\Delta$ values for $\mathrm{Fe}^{\mathrm{III}}$ in the Mössbauer spectra and with the $T_{\mathrm{g}}$ values, determined by DTA. These results suggest that the macroscopic physical properties of the "superionic conducting" vanadate glass ( $\sigma$ and $T_{\mathrm{g}}$ ) were determined by the local distortion of the structural units $\left(\mathrm{FeO}_{4}\right.$ and $\mathrm{VO}_{4}$ tetrahedra), ${ }^{[24]}$ evidenced by the " $T_{\mathrm{g}}-\Delta$ rule". ${ }^{[5,13,16,18-21]}$ The electrical conduction of superionic conducting Agl-containing vanadate glass originated from the migration of mobile $\mathrm{Ag}^{+}$ions surrounded by $\mathrm{I}^{-}$ions, whereas $\mathrm{Ag}^{+}$ions originating from $\mathrm{Ag}_{2} \mathrm{O}$ played a role NWM, similar to several alkali and alkaline-earth ions. Low-temperature Mössbauer study of $5 \mathrm{Ag}_{2} \mathrm{O} \cdot 10 \mathrm{Fe}_{2} \mathrm{O}_{3} \cdot 85 \mathrm{~V}_{2} \mathrm{O}_{5}$ and $45 \mathrm{Ag}_{2} \mathrm{O} \cdot 10 \mathrm{Fe}_{2} \mathrm{O}_{3} \cdot 45 \mathrm{~V}_{2} \mathrm{O}_{5}$ glasses ${ }^{[25]}$ was consistent with the structural change of the glass matrix described above.

In studying $x \mathrm{AgI} \cdot(75-x) \mathrm{Ag}_{2} \mathrm{O} \cdot \mathrm{Fe}_{2} \mathrm{O}_{3} \cdot 24 \mathrm{~V}_{2} \mathrm{O}_{5}$ and $x$ Lil $\cdot(38-x) \mathrm{Li}_{2} \mathrm{O} \cdot 6 \mathrm{Fe}_{2} \mathrm{O}_{3} \cdot 56 \mathrm{~V}_{2} \mathrm{O}_{5}$ glasses, lkeda et al. calculated the fractions of ionic conduction and electronic conduction by combining the results of $A C$ and $D C$ measurements. ${ }^{[26]}$ In the Mössbauer study of alkali iron vanadate glasses, $x \mathrm{R}_{2} \mathrm{O} \cdot 10 \mathrm{Fe}_{2} \mathrm{O}_{3} \cdot(90-x) \mathrm{V}_{2} \mathrm{O}_{5}$ glasses $(\mathrm{R}=\mathrm{Li}, \mathrm{Na}, \mathrm{K}$; $x=20,40$ ), cationic conduction was effective in increasing the conductivity. ${ }^{[15]} \mathrm{Li}^{+}$-containing conductive vanadate glass, $\mathrm{LiFeVPO}_{x}$, was developed as a cathode active material for lithium ion battery (LIB). ${ }^{[12,27,28]} \mathrm{LiFeVPO}_{x}$ glass annealed at $450^{\circ} \mathrm{C}$ for $60 \mathrm{~min}$ showed an increase of $\sigma$ from $1.3 \times 10^{-6}$ to $1.0 \times 10^{-3} \mathrm{~S} \mathrm{~cm}^{-1}$, together with a marked increase of the specific discharge- and charge-capacities from $50 \mathrm{mAhg}^{-1}$ to 150 mAhg $^{-1} .^{[27]}$ Mössbauer study of $\mathrm{LiFeVPO}_{x}$ glass showed a decrease of $\Delta$ for Fe'll from $0.99 \mathrm{~mm} \mathrm{~s}^{-1}$ to $0.50 \mathrm{~mm} \mathrm{~s}^{-1}$, reflecting the structural relaxation of the network composed of distorted $\mathrm{FeO}_{4}$ and $\mathrm{VO}_{4}$ tetrahedra. These 
experimental results suggested that the structural relaxation, caused by the heat treatment, was effective even when the ionic conduction coexisted with the electronic conduction.

Highly conductive vanadate glasses have a lot of industrial applications, such as cathode active material for LIB, solid state electrolyte, sensor, electron-emitting needle, static electricity protecting material, conductive glass paste and the hyperfine processing material combined with FIB, electrons and laser. For these applications, vanadate glass is a very suitable material because of its flexibility in "tuning" the conductivity by the heat treatment. The authors wish this functional material could contribute to the development of science and technology all over the world.

\section{SUMMARY}

1. Electrical conductivity of conductive vanadate glass is promoted by the structural relaxation of the network composed of the structural units like $\mathrm{VO}_{4}, \mathrm{FeO}_{4}$ and $\mathrm{VO}_{5}$ units, causing an increased probability of the small polaron hopping.

2. In the case of highly conductive vanadate glasses with $\sigma$ higher than $10^{-4} \mathrm{~S} \mathrm{~cm}^{-1}$, $n$-type semiconductor model becomes predominant over the small polaron hopping.

3. Heat treatment of vanadate glasses at temperatures higher than $T_{\mathrm{g}}$ or $T_{\mathrm{c}}$ resulted in a systematic decrease in the $E_{\mathrm{a}}$ for the conduction, which could be correlated to the energy gap between the donor level and the $C B$, mainly composed of anti-bonding $4 s$-orbitals.

4. Electron configurations of $3 d^{10}$ and $3 d^{9}$ are favorable for the highly conductive vanadate glass because the carriers (electrons) necessarily have to occupy the $4 s$ orbitals which form isotropic chemical bonds.

5. Valence electrons in the fully or almost fully occupied $3 d$-orbitals could effectively shield the nuclear charge. This might be effective for the smooth carrier flow in the $\mathrm{CB}$.

Acknowledgment. This manuscript was submitted to the Proceedings of MECAME2015 (First Mediterranean Conference on the Applications of the Mössbauer Effect held in 2015), which was organized in honor of Dr. Svetozar Musić, Ruđer Bošković Institute, Zagreb. The authors (TN \& SK) would like to express their sincere thanks for his kindness and friendship. They are also indebted to Mr. Ken-ichi Kobayashi, Art-beam Corporation, Tokyo, for his useful discussion.

\section{REFERENCES}

[1] T. Nishida, Japan Patent No. 4085139, 2008

[2] T. Nishida, M. Tokunaga, Y. Sugata and S. Kubuki, J. Radioanal. Nucl. Chem. 2005, 266, 171.

[3] N. F. Mott, Adv. Phys. 1967, 16, 49.

[4] T. Nishida, J. Kubota, Y. Maeda, F. Ichikawa and T. Aomine, J. Mater. Chem. 1996, 6, 1889.

[5] T. Nishida, Chemical Applications, in: Introduction to the Mössbauer Spectroscopy -Fundamentals and Applications (Ed. F. E. Fujita), Agne Gijutsu Center, Tokyo, 1999, Ch 4, pp. 169-266. (in Japanese)

[6] T. Nishida and Y. Takashima, Bull. Chem. Soc. Jpn. 1987, 60, 941.

[7] T. Nishida, M. Ogata and Y. Takashima, Bull. Chem. Soc. Jpn. 1987, 60, 2887.

[8] T. Nishida, M. Ogata and Y. Takashima, J. Non-Cryst. Solids 1987, 95/96, 241.

[9] T. Nishida, S. Saruwatari and Y. Takashima, Bull. Chem. Soc. Jpn. 1988, 61, 2343.

[10] K. Fukuda, A. Ikeda and T. Nishida, Solid State Phenom. 2003, 90/91, 215.

[11] T. Nishida, Japan Patent Nos. 3854985, 2006 \& 5164072, 2012

[12] T. Nishida and S. Kubuki, Mössbauer Study of New Electrically Conductive Glass in: Mössbauer Spectroscopy: Applications in Chemistry, Biology, Nanotechnology, Industry and Environment, (eds. by V. K. Sharma, G. Klingelhöfer and T. Nishida), John Wiley \& Sons, Hoboken, NJ, 2013, pp. 542-551.

[13] S. Kubuki, H. Sakka, K. Tsuge, Z. Homonnay, K. Sinkó, E. Kuzmann, H. Yasumitsu and T. Nishida, J. Ceram. Soc. Jpn. 2007, 115, 776.

[14] K.H. Sun, J. Am. Ceram. Soc. 1947, 30, 277.

[15] S. Kubuki, K. Matsuda, K. Akiyama and T. Nishida, J. Radioanal. Nucl. Chem. 2014, 299, 453.

[16] I. Furumoto, S. Kubuki and T. Nishida, Radioisotopes 2012, 61(9), 463.

[17] S. Kubuki, H. Masuda and T. Nishida, J. Radioanal. Nucl. Chem. 2013, 295, 1123.

[18] T. Nishida, Mössbauer Effect in Inorganic Glasses, in Mössbauer Spectroscopy of Sophisticated Oxides, (Eds. A. Vértes and Z. Homonnay, Akadémiai Kiadó), Budapest, 1997, Ch. 2, p. 27-87.

[19] T. Nishida, H. Ide and Y. Takashima, Bull. Chem. Soc. Jpn. 1990, 63, 548.

[20] S. Kubuki, K. Matsuda, K. Akiyama, Z. Homonnay, K. Sinkó, E. Kuzmann and T. Nishida, J. Non-Cryst. Solids 2013, 378, 227.

[21] T. Nishida, M. Suzuki, S. Kubuki, M. Katada and Y. Maeda, J. Non-Cryst. Solids 1996, 194, 23. 
[22] K. Matsuda, S. Kubuki and T. Nishida, AIP Conf. Proc. 2014, 1622, msms2014, 3.

[23] S. Kubuki, H. Masuda, K. Akiyama, I. Furumoto and T. Nishida, Hyperfine Interact. 2012, 207, 61.

[24] T. Nishida, H. Ide, Y. Takashima, T. Yagi, S. Tomariguchi, T. Ishizuka and A. Sakai, J. Mater. Sci. 1989, 24, 1687.

[25] T. Nishida, H. Ide and Y. Takashima, J. Ceram. Soc. Jpn. 1989, 97(3), 284.
[26] A. Ikeda, K. Fukuda and T. Nishida, Croatia Chemica Acta 2004, 77(1-2), 259.

[27] T. Nishida, Y. Yoshida, Y. Takahashi, S. Okada and J. Yamaki, J. Radioanal. Nucl. Chem. 2008, 275(2), 417.

[28] H. Kurimoto, T. Nishida, S. Okada and J. Yamaki, J. Ceram. Soc. Jpn. 2009, 116, 637. 